\title{
Politics of Language in "Korean style Multiculturalism": Utilization of Filipino Language in Korean Language Textbooks for Marriage Migrants
}

Ronel O.Laranjo

Filipino, the national language of the Philippines, is used in other countries not just to promote the language and Philippine culture. This paper examines how the language is utilized in order to facilitate the mastery of the Korean language as well as the assimilation of marriage migrants into Korean society. The Republic of Korea has recently been shifting towards a multicultural society. This shift has given way to a government-sponsored multicultural policy, which seems flawed and has given birth to another social problem. According to Korean scholars Kim (2011), Watson (2010), and Lee (2015), the concept of multiculturalism is quite problematic because it promotes assimilation rather than the recognition of different cultures. This paper also aims to examine the dynamics of the politics of language in "multicultural" Korea by analyzing texts written in Filipino/Tagalog distributed by different Korean government agencies. These texts will be described, interpreted, and explained using Fairclough's critical discourse analysis.

Keywords: multiculturalism, Filipino language, marriage migrants, politics of language, critical discourse analysis

Filipino is a lingua franca not just in the Philippines but also in other countries where Filipinos reside, work, and study such as in the United States of America, Canada, China, Saudi Arabia, Kuwait, Japan, England, Norway, New Zealand, Malaysia, and Korea. It is now called Global Filipino, a term which had its linguistic debut at the 1st International Conference on Filipino as a Global Language (Yap, 2012). The propagation of the language to different countries is a consequence of the Overseas Filipino Workers (OFW) phenomenon whose number has reached 2.4 million as of 2016. There are many studies (Mabanglo, 1997; Oue, 1997; Ramos \& Mabanglo, 2012; Laranjo \& Shin, 2016) on how the language as well as Philippine culture is being taught and learned by learners abroad, but there are few which examine how exactly this language is used. This paper will address this gap by examining how it is utilized in Korean society.

\section{Multiculturalism and Filipinos in Korea}

South Korea, one of the most ethnically homogenous nation-states in the world, is experiencing significant changes in its ethnic composition for 
the first time in its history (Kim, 2012). It is fast becoming a multicultural society. This is due to the influx of migrants in the republic owing to labor shortage, which is a result of the low birthrate since the 1990s. As of 2016, there are over two million foreign residents in Korea which account for almost four percent of the country's population. Based on the data by Korean Immigration Service (Table 1), the highest number of foreigners since 2012 is the Chinese, which is divided into pure Chinese and the Chinese-Koreans. Meanwhile, Filipinos rank sixth. Filipinos residing in Korea are composed of workers, diplomats, businessmen, professionals, students, and marriage migrants.

\begin{tabular}{|l|r|r|r|r|r|}
\hline \multicolumn{1}{|c|}{ Country of Origin } & \multicolumn{1}{c|}{$\mathbf{2 0 1 2}$} & \multicolumn{1}{c|}{$\mathbf{2 0 1 3}$} & \multicolumn{1}{c|}{$\mathbf{2 0 1 4}$} & \multicolumn{1}{c|}{$\mathbf{2 0 1 5}$} & \multicolumn{1}{c|}{$\mathbf{2 0 1 6}$} \\
\hline China & \multicolumn{1}{c|}{698,444} & 778,113 & 898,654 & 955,871 & $1,016,607$ \\
\hline China (Korean Chinese) & 447,877 & 497,989 & 590,856 & 626,655 & 627,004 \\
\hline United States & 130,562 & 134,711 & 136,663 & 136,758 & 149,384 \\
\hline Vietnam & 120,254 & 120,069 & 129,973 & 138,660 & 140,222 \\
\hline Thailand & 45,945 & 55,110 & 94,314 & 93,348 & 100,860 \\
\hline Philippines & 42,219 & 47,514 & 53,538 & 54,977 & 56,980 \\
\hline Uzbekistan & 34,688 & 38,515 & 43,852 & 47,103 & 54,490 \\
\hline Japan & 57,174 & 56,081 & 49,152 & 47,909 & 51,297 \\
\hline Indonesia & 38,018 & 41,599 & 46,945 & 46,538 & 47,606 \\
\hline Cambodia & 24,610 & 31,986 & 38,395 & 43,209 & 45,832 \\
\hline Total & $1,445,103$ & $1,576,034$ & $1,997,618$ & $1,899,519$ & $2,049,441$ \\
\hline
\end{tabular}

Table 1. No. of foreign residents in Korea by country (Top 10) (Korean Immigration Service, 2016).

International marriages also increased to address the declining marriage rate of Korean men with local women. Marriage migrants, that is, men or women who migrate to Korea to marry a Korean citizen, drastically increased, and based on the data from Korean Immigration Service (Table 2), Filipino marriage migrants in 2016 rank fourth overall after China, Vietnam, and Japan. It can also be observed from the statistics that there are more female marriage migrants than male from most of the countries except the United States.

\begin{tabular}{|l|c|c|c|}
\hline Country of Origin & Male & Female & Total \\
\hline China & 11,629 & 45,301 & 56,930 \\
\hline Vietnam & 1,324 & 40,479 & 41,803 \\
\hline Japan & 1,218 & 11,892 & 13,110 \\
\hline Philippines & 334 & 11,272 & 11,606 \\
\hline Cambodia & 61 & 4412 & 4473 \\
\hline United States & 2,537 & 817 & 3,354 \\
\hline
\end{tabular}




\begin{tabular}{|l|c|c|c|}
\hline Country of Origin & Male & Female & Total \\
\hline Thailand & 77 & 3,105 & 3,182 \\
\hline Mongolia & 117 & 2,264 & 2,381 \\
\hline Uzbekistan & 87 & 2,215 & 2,302 \\
\hline Russia & 84 & 1,098 & 1,182 \\
\hline
\end{tabular}

Table 2. No. of Marriage Migrants in Korea by Country and Sex (Korean Immigration Service, 2016)

Multiculturalism is the Korean government's response to globalization and to its own internal problems of labor shortage as a result of declining birth and marriage rates. However, this government policy seems to be flawed and has given birth to another social problem. According to Korean scholars, the concept of multiculturalism is quite problematic because it promotes assimilation instead of recognition of different cultures. According to Iain Watson (2010), state-led multiculturalism is an expedient policy of cultural assimilation into a privileged and homogeneous Korean culture. Joon Kim (2011) observes that the bulk of the government's initiatives such as the Basic Law Concerning the Treatment of Foreigners in Korea of 2007 and the Multicultural Family Support Law of 2008 were implicitly geared towards the assimilation of marriage migrants and their children into Korean society. Yong Seung Lee (2015) also explains how the government staged multiculturalism as the new norm in Korea and describes it as "Korean style multiculturalism policy" (p. 92), which is nearly similar to assimilation policy.

In this kind of setup, a family with international marriage is labeled as "damunhwa/ 다문화" or "multicultural families" to differentiate them from a typical Korean family. This term implies the "othering" of these new members in a society with a strong and rich traditional culture. Kim (2011) argues that many of the multicultural programs are one-way, top-down efforts that impose a liberal paternalistic agenda on how to deal with individuals from diverse cultural backgrounds, and that cultural paternalism is evident in said programs. Cultural paternalism refers to the dominant cultural group's underlying attitudes and policies that, albeit altruistic in intent, define the terms of dealing with ethnic diversity (p. 1,597).

In line with Kim's argument, the researcher suggests that politics of language is also present in this "Korean style multiculturalism" since culture and language are inextricably linked. This study adopts the definition of politics as the art and practice of gaining power, control, or influence, and is capable of manipulation with the use of linguistic strategies or tactics and political persuasion (Yap, 2013). The dominant culture and languageKorean in this context-dictates what is best for the minority culture and its language; therefore the minority-the marriage migrants-becomes 
passive and subject to the dominion of the father culture and language. This paternalistic attitude is perpetuated and maintained not just through the Korean language but also by using the immigrant's native language. This paper aims to analyze texts written in Filipino/Tagalog language distributed by different Korean government agencies to examine the dynamics of the politics of language in multicultural Korean society. More particularly, this paper aims to answer the following questions:

1. Why are there Filipino/Tagalog translated texts in multicultural society of Korea?

2. What are the sociocultural and discursive practices propagated in Filipino/Tagalog translated texts?

3. How is Filipino/Tagalog language utilized in texts produced in "Korean style multiculturalism"?

\section{Review of Related Literature}

In his article "The Politics of Culture in Multicultural Korea," Kim (2011) discusses the role of multicultural family support centers in multicultural Korea and the kind of multiculturalism these centers propagate. He argues that despite their impressive scope and resource allocation, the contents and approaches of the newly emerging multicultural programs reproduce, rather than minimize, the cultural hierarchy between Koreans and nonKoreans. Kim also employs the concepts of cultural paternalism and cultural fetishism in framing his arguments. While Kim's study focuses on culture, this paper will focus more on the language and ideology propagated in the written texts produced in the same context to further prove that politics of language and culture exists in multicultural society of Korea.

Jeonghye Son (2012) uses the framework of imagined communities to analyzed two Korean language textbooks designed for foreign brides and workers in Korea. According to Son, there are three identity options for imagined learners, that is, foreign brides and workers: (1) they are from less-developed countries; (2) they have a limited capacity for professional work; and (3) they are culturally and socially incompetent. While Son's study focuses on the image of the foreign brides and workers in Korea in Korean language textbooks, this paper research will focus on the sociopolitical and sociolinguistic discourses as reflected in Filipino/Tagalog translated textbooks for marriage migrants.

\section{Critical Discourse Analysis}

Critical discourse analysis (CDA) is a research movement that aims to (1) analyze discourse practices that reflect or construct social problems; (2) investigate how ideologies can become frozen in language and find ways 
to break the ice; (3) increase awareness on how to apply these objectives to specific cases of injustice, prejudice, and misuse of power; (4) demonstrate the significance of language in the social relations of power; (5) investigate how meaning is created in context; and (6) investigate the role of speaker/ writer, purpose, and authorial stance in the construction of discourse (Bloor \& Bloor, 2007). CDA examines discourse based on how people use language in society to achieve certain goals, especially those that are related to social maintenance and social change. According to Norman Fairclough (1995), one of the frontrunners of CDA:

In using the term "discourse" I am claiming language use to be imbricated in social relations and processes which systematically determine variations in its properties, including the linguistic forms which appear in texts. (p. 73)

Fairclough (1995) adds that language and ideology are interconnected as language is a material form of ideology and language is invested by ideology. In line with this, he also mentions Gramci's concept of hegemony, which cuts across and integrates economy, politics, and ideology, yet ascribes an authentic place to each of them within an overall focus on politics and power, and on the dialectical relations between classes and class fragments. This approach he developed focuses on the links between social practices and language, the systematic investigation of connection between the nature of social processes and the properties of language in the form of texts. Fairclough summarized his methodological analysis in Figure 1.

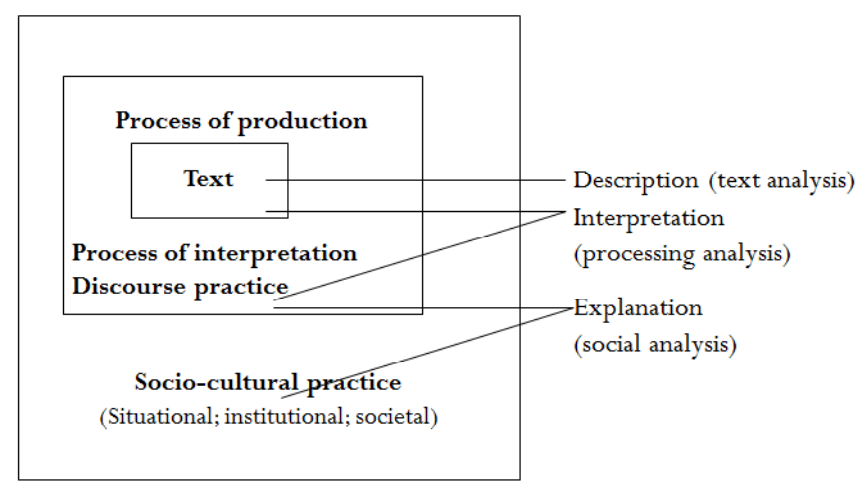

Figure 1. Fairclough's model of critical discourse analysis (Fairclough, 1995, p. 98)

Dimensions of discourse Dimensions of discourse analysis

A text is any written or spoken language produced in any instance of language use. In CDA, a text is described first based on its linguistics characteristics (Description). The text then is interpreted through the process of production and discourse practice (Interpretation). Discourse 
practice is defined as the production, distribution, and consumption of a text (Fairclough, 1995). Finally, the text can be explained using discourse and sociocultural practices (Explanation). Discourse is embedded in the immediate situation, in the wider institution or organization, and at a societal level where sociocultural practice takes place. Fairclough sums it up this way:

A special feature of the approach is that the link between sociocultural practice and text is mediated by discourse practice; how a text is produced or interpreted, in the sense of what discursive practices and conventions are drawn from what order(s) of discourse and how they are articulated together, depends upon the nature of the sociocultural practice which the discourse is part of; the nature of the discourse practice of the text production shapes the text, and leave 'traces' in surface features of the text; and the nature of the discourse practice of text interpretation determines how the surface features of a text will be interpreted. (p. 97)

This approach will serve as a guide in examining how "Korean style multiculturalism" utilizes one of the marriage migrants' languages, the Filipino/Tagalog language, in textbooks created for them. The researcher was able to gather six textbooks translated to Filipino/Tagalog language. The textbooks were about basic Korean language published by the Ministry of Gender Equality and Family, and Women's Policy Division of Ministry of Agriculture and Forestry.

\section{Text Analysis:}

\section{Filipino/Tagalog Textbooks for Marriage Migrants}

The assimilation concept of "Korean style multiculturalism" is very much evident in the Multicultural Family Support Law of 2008:

It aims to foster stable family life for the members of multicultural families and to encourage their social integration by urging the government and the various organizations to establish and implement the necessary systems and programs. (Kim, 2011, p. 1,591)

This law has provisions for basic informational and educational materials about Korea in order to facilitate the adaptation of migrants to Korean society (Article 6) and to minimize the impact of the language barrier. Local organizations were also encouraged to establish translation and interpretation services in multiple languages (Article 11). As a result of 
this law, different government agencies created books, pamphlets, websites, and other paraphernalia translated to the mother language of the major marriage migrant groups such as Chinese, English, Vietnamese, Filipino/ Tagalog, Japanese, Cambodian, Mongolian, Thai, Russian and others. The marriage migrants' languages were used to facilitate their integration in Korean society.

In the case of Filipino/Tagalog language, there are two textbooks produced by different government agencies to help facilitate the assimilation of Filipina marriage migrants.

The Ministry of Gender Equality and Family (MOGEF), a cabinet level division of the Korean government whose main works are related to the welfare of family, women, and the youth, including the multicultural family, published the book entitled 여성 결혼이민자를 위한 한국어교재 (타갈로그어 초급) [Pangunahing Aralin sa Hangugo (Basic)] (Fetalvero, 2007)], about the Korean language translated in Tagalog/Filipino. The textbook has also translations in English, Vietnamese, and Chinese. The women's division of Ministry of Agriculture and Forestry, now Ministry of Agriculture, Food and Rural Affairs (MAFRA), which focuses on the food industry, production and rural community, also published a book for female marriage migrants entitled 우리 엄마의 한국어 (초급) (타갈로그) [My Mom's Korean (Beginner Level) (Tagalog)] (Jo, Kim, Woo, Woo, \& Lee, 2007). This has also English, Vietnamese, and Chinese versions.

The topics in the textbooks are listed as follows:

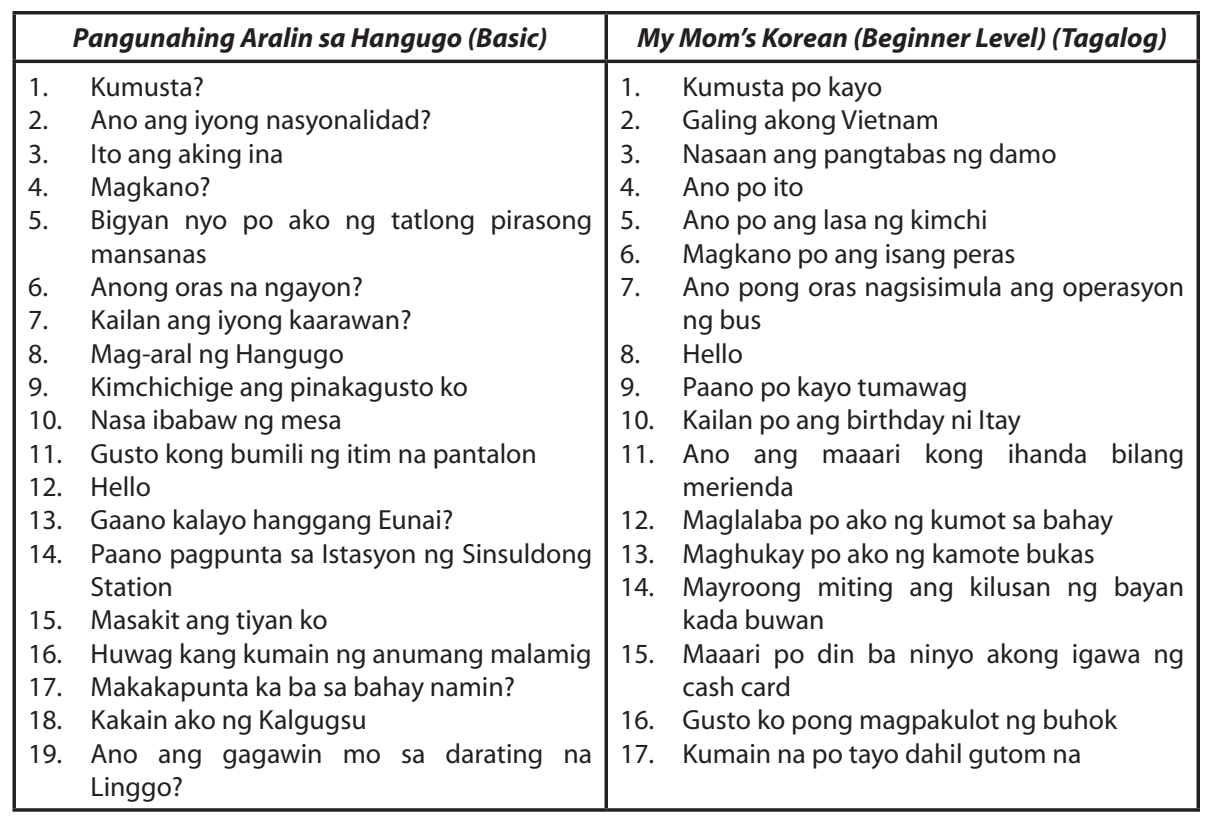




\begin{tabular}{|c|c|}
\hline Pangunahing Aralin sa Hangugo (Basic) & My Mom's Korean (Beginner Level) (Tagalog) \\
\hline $\begin{array}{l}\text { 20. Paki padala sa Pilipinas } \\
\text { 21. Nakapunta ka na bas a palengke ng } \\
\text { Dongdaemon? } \\
\text { 22. Nakasuot ng sombrero } \\
\text { 23. Anong pagkain ang lulutuin natin sa } \\
\text { Chusok } \\
\text { 24. Makinig ng mabuti sa guro. }\end{array}$ & $\begin{array}{l}\text { 18. Wag mo po lagyan ng dahon sibuyas ang } \\
\text { sabaw ng seaweed } \\
\text { 19. Maaari na po kayong umalis bago } \\
\text { magsimulang magsaka } \\
\text { 20. Kailangan kung patuyuin ang mga labanos } \\
\text { at pulang sili } \\
\text { 21. Dahil sa malakas na ulan, nangangamba } \\
\text { ako sa pagtatanim ng pulang sili } \\
\text { 22. Tulungan na po kita sa paghahanda ng } \\
\text { hapagkainan } \\
\text { 23. Sipon yata ito } \\
\text { 24. Lumalabas ngayon si Gahee mula sa } \\
\text { paaralan. }\end{array}$ \\
\hline
\end{tabular}

Table 3. Topic of Filipino/Tagalog textbooks for Filipina marriage migrants (Fetalvero, 2007 \& Jo, Kim, Woo, Woo, \& Lee, 2007)

여성 결혼이민자를 위한 한국어교재 [Pangunahing Aralin sa Hangugo] (Basic)](Fetalvero, 2007) is composed of 24 chapters. Each chapter is divided into Paksa, which introduces the topic of the chapter; Pag-uusap, which presents a dialogue; Sitwasyon, which explains the situation; Talahulugan, which lists the important vocabularies and their meaning or translation in Tagalog; Balarila, which gives grammatical explanation; Pagbigkas, which demonstrates the pronunciation of words; and Pagsasanay, which contains exercises related to the grammatical lessons, including exercises focusing on Pagbasa and Pagsulat. Pictures 1 and 2 are examples of a chapter taken from the e-book version of the textbook. There is also an appendix found at the end of the textbook entitled "Gabay sa Pamumuhay ng Mga Imigranteng Kababaihang May Asawa at ng kanilang Anak" [Guide for Living in Korea for Female Marriage Migrants and their Children], which contains information about staying in Korea and nationality acquisition; studying Korean; programs for family and livelihood; assistance and laws; health; taking care of a child; and security for low-wage earners and women in the farming and fishing sector.

The Korean text or Hangeul is the main text, which could be found on the left or upper side, followed by the Filipino/Tagalog translation on the right side and below. It could be observed that Filipino/Tagalog is the dominant language as it is used not just to give the equivalent translation of the Korean text but also to introduce the topic, to give directions to the students, and to explain the situation. This textbook is also given the title Pansariling Pag-aaral ng Hangugo para sa mga Imigranteng Kababaihan, which implies that this book is intended for self-study.

우리 엄마의 한국어 (초급) (타갈로그) [My Mom's Korean (Beginner Level) (Tagalog)] (Jo et al., 2007) is also composed of 24 lessons. The lessons are divided into: 도입 [introduction], which states the topic; 대화 


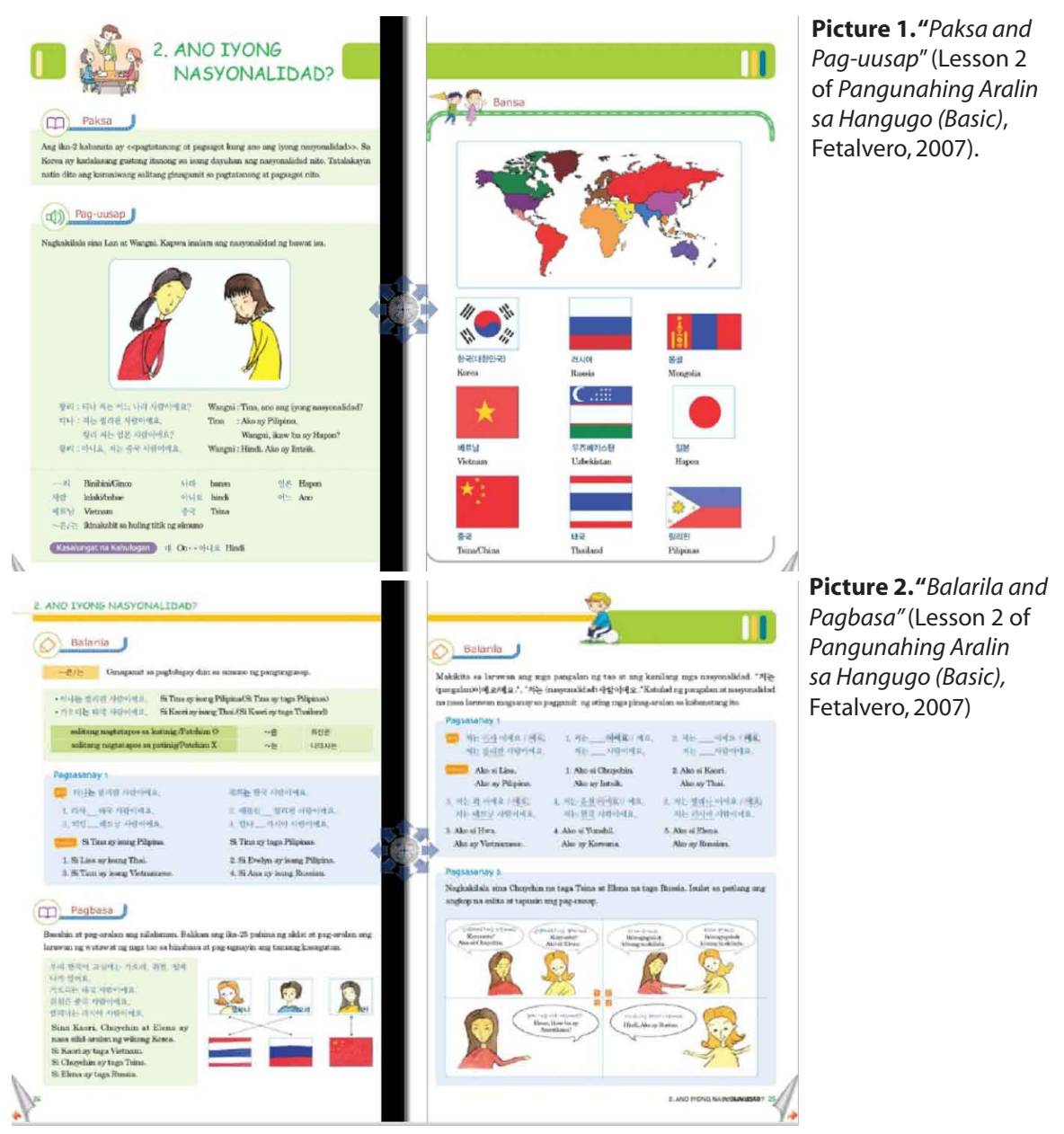

[conversation], which presents the dialogue; 문법 및 표현 [grammar and expressions], which explains the grammatical rules and meanings of expressions used in the conversation; exercises for 말하기 [speaking], 쓰기 (writing), 듣기 [listening], and 인터뷰 과제 [interview assignment], which are exercises related to speaking; 관련 어휘 및 표현 [related vocabulary and expressions], which provides additional vocabularies and expressions related to the topic; and 계절과 절기 (seasons and subdivisions of seasons), which explains the different seasons and its connection to agriculture. There are also additional sections in the textbooks with the heading 우리고장 이모저모 (Let's fix this and that), which features different agricultural products from different provinces in Korea. There is also a recipe or how to make food or drinks. These special sections appear after every six lessons. Pictures 3-6 show the content of the textbook. 


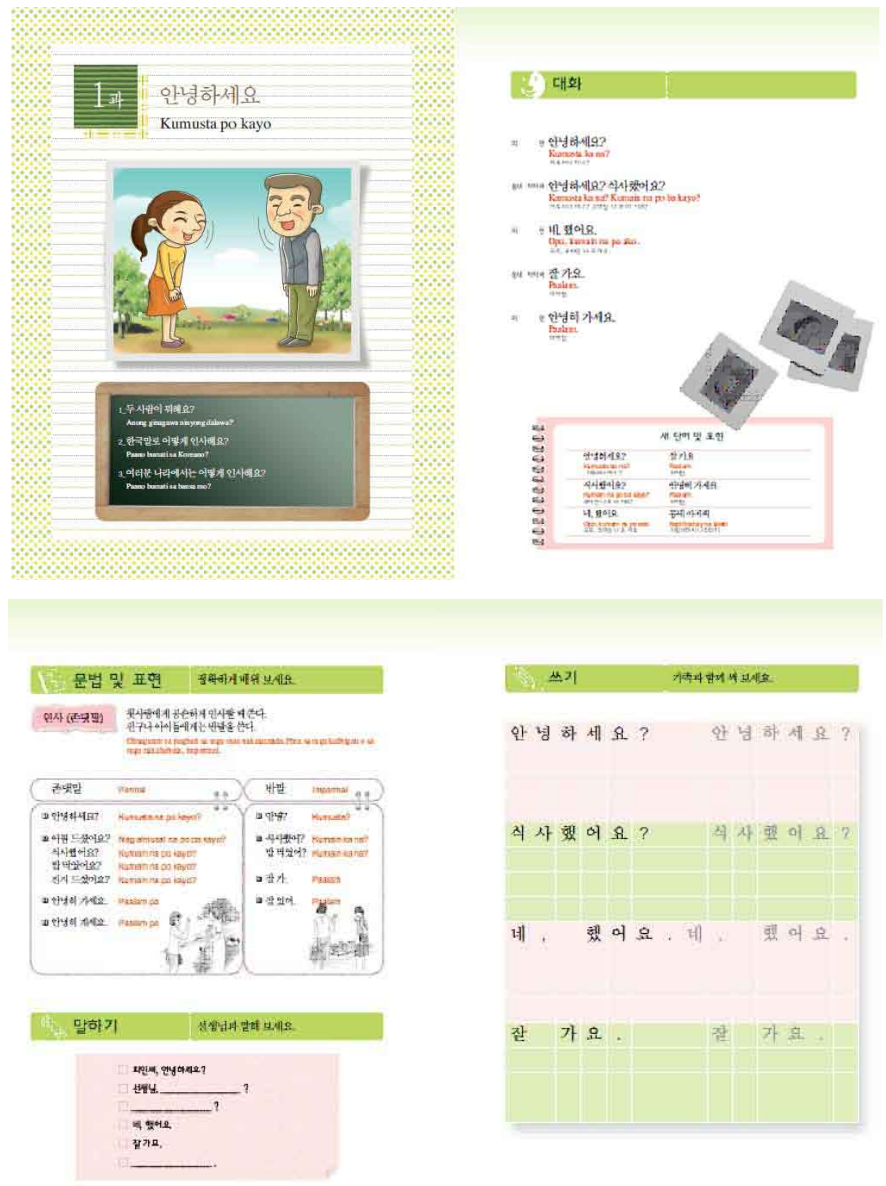

Picture 3."도입"

(Introduction) and" 대화" (Dialogue) (Lesson 1 of My Mom's Korean (Beginner Level) (Tagalog), Jo et al., 2007)..

Picture 4."문법 및 표현" (Grammar and Expressions) and "쓰기" (Writing) (Lesson 1 of My Mom's Korean (Beginner Level) (Tagalog), Jo et al., 2007).

Picture 5: 듣기 (listening), 인터뷰 과제

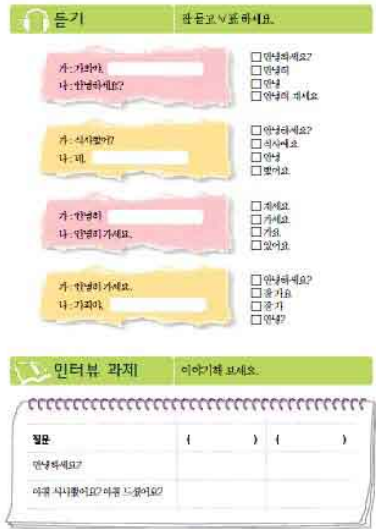
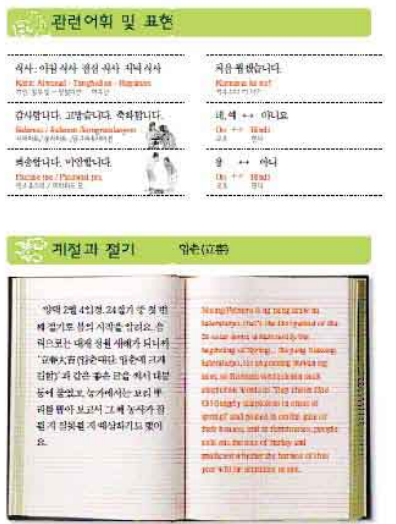
(interview assignment), 관련어휘 및 표현 (related vocabulary and expressions) and 계절과 절기(season and subdivisions of seasons) (Lesson 1 of My Mom's Korean (Beginner Level) (Tagalog), Jo et al., 2007). 


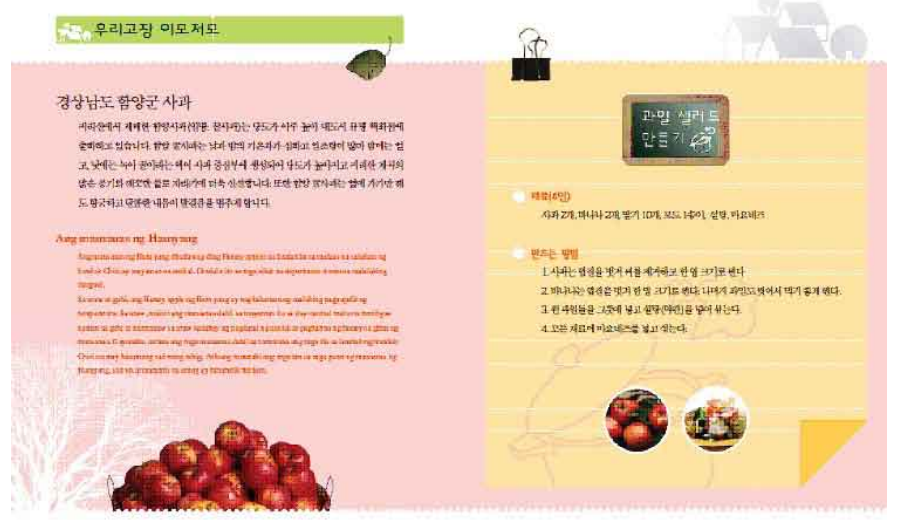

이모저모 [Let's fix this and that], 만들기 [recipe] (Jo et al., 2007).

The main text in this textbook is in Korean, which could be found on the left or upper side, followed by the Filipino/Tagalog translation on the right side and below. In the 대화 (conversation) section seen in Picture 3, the first text is Korean in blank ink, followed by the Filipino/Tagalog in red ink, and under it is a Hangeul which is based on the pronunciation of the Filipino/ Tagalog sentence. Example:

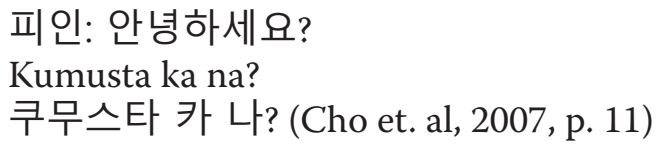

According to the authors' introduction, the Korean pronunciation of the Filipino/Tagalog translation serves as a guide for the Korean husband and other family members who also want to study the mother's native language. It could be observed that Korean is the dominant language used in this textbook as the headings, the names of the people in the dialogues, and other parts are not translated to Filipino/Tagalog. The title of the book, the introduction, the table of contents, and the textbook outline are not translated to Filipino/Tagalog. This textbook is a supplementary material for roving classes offered by the ministry and could also be use in self-study.

Both textbooks are translations of the original Korean text. The title in Korean, 여성 결혼이민자를 위한 한국어교재 (타갈로그어 초급) (Jo etal., 2007) indicates that the book is for female marriage migrants, but the title in Filipino/Tagalog on the cover page does not indicate this. However, it is indicated in the introduction that the title in Filipino is Pansariling Pag-aaral $n g$ Hangugo para sa mga Imigranteng Kababaihan. In the case of My Mom's Korean Language (Jo et al., 2007), the Korean title 농촌 여성결혼이민자를 위한 한국어, states that the book is for female marriage migrant who are in the rural or farming village. The term 우리 엄마 literally means "our 
mom," which is usually uttered by the children to refer to their mother. This is translated in English as "my mom" and is not at all translated to Filipino. Both textbooks use the word "Tagalog" to refer to the Philippines' language, but in actuality, the textbook uses Filipino. The researcher uses Filipino and Tagalog to refer to the same language.

Pangunahing Aralin sa Hangugo (Basic) (Fetalvero, 2007) utilizes the Filipino language more than My Mom's Korean (Beginner Level) (Tagalog) (Jo et al., 2007), which uses Korean language as the main text. The Filipino/ Tagalog translation of Pangunahing Aralin sa Hangugo (Basic) is more natural and only has a few grammatical errors. However, My Mom's Korean (Beginner Level) (Tagalog) has many grammatical and typographical errors like the sample conversation below:

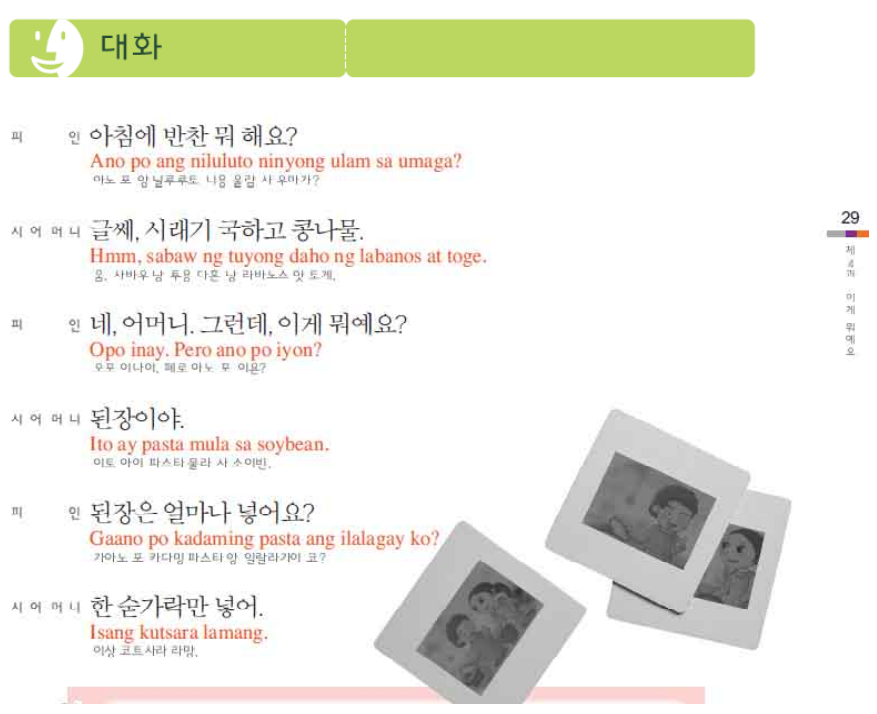

Picture 7. Sample typographical and grammar errors in My Mom's Korean, Jo et al., 2007).

In the conversation above, 이게 should be translated as ito instead of 이게 and pasta should be paste for된장. 시래기 is best translated as siraegi, its original name in Korea, than giving its descriptive translation, sabaw ng tuyong daho[n] ng labanos [dried radish leaf soup]. These errors have implications to the Filipina learner and also to the husband and family members who are learning Filipino/Tagalog language using the Hangeul writing under the Filipino/Tagalog text. It seems that the translator translated the text from English to Filipino rather than from Korean to Filipino as there are untranslated English texts in the 계절과 절기 [season and subdivisions of seasons] section. It is observed that the name of the translator, Necita Fetalvero, is mentioned in Pangunahing Aralin sa Hangugo (Basic) while no translator is mentioned in My Mom's Korean (Beginner Level) (Tagalog). 


\section{Discourse Practices: Identities of Marriage Migrants}

Both textbooks are multimodal texts as they are composed of pictures, images, and other texts that simulate the real world like posters, letters, and places. As a genre, they fall under the category of textbook because they are intended for teaching basic Korean grammar to Filipino marriage migrants. The textbooks are also filled with cultural notes and practices specific to Korean society, including terms for different food, places, things, seasons, occasions, holidays, and customs.

The dialogue or conversation discourse in Pangunahing Aralin sa Hangugo (Basic) (Fetalvero, 2007) uses the question-and-answer format more. The main character Tina interacts with her husband, child, and mother-in-law, as well as with fellow foreigners and different members of Korean society such as neighbors, teacher, doctor, vendor, and police who she encounters at the school, market, hospital, street, etc. The conversations take place in Seoul, the capital city of Korea, as there is mention of places located in the area such as Sinsuldong and Dongdaemun market. On the other hand, in the dialogue section of My Mom's Korean (Beginner Level) (Tagalog) (Jo et al., 2007), most of the conversations are between Pi-in, one of the main characters, and her husband, mother-in-law, sister-inlaw, fellow foreigners, and husband's friends. The dialogues happen in the house, farming site, market, and neighborhood. She also goes to the bank, hair salon, and hospital, where she exchanges dialogues with the teller, beautician, and doctor, respectively.

In the textbooks, the main characters are both women who are married to Koreans because they are the target reader or learner. Pangunahing Aralin sa Hangugo (Basic) (Fetalvero, 2007) targets the marriage migrants who are living in the city while the expected learners of My Mom's Korean (Beginner Level) (Tagalog) (Jo et al., 2007) are women from the countryside, specifically the ones who married farmers. Women are expected to be domesticated because most of their dialogues happen inside their houses as they help their mothers-in-law and their husbands as well prepare something. The main character in Pangunahing Aralin sa Hangugo (Basic) is seen helping her mother-in-law prepare food for Chuseok, Korea's biggest holiday, and do household chores like the laundry, cooking, going to the market, and taking care of their child. Pi-in, the main character in My Mom's Korean (Beginner Level) (Tagalog), aside from doing the household chores, also helps her husband in planting and harvesting agricultural products. It is also interesting to note that in both textbooks, the husband is portrayed as loving and caring, based on the dialogues. Tina's husband, for example, asks about her condition and offers to take her to the hospital when she doesn't get better: 


$\begin{array}{ll}\text { 여보, 어디 아파요? } & \text { Asawa: Mahal, saan ang masakit? } \\ \text { 녜, 배가 아파요. } & \text { Tina :Masakit ang tiyan ko. } \\ \text { 약은 먹었어요? } & \text { Asawa: Uminom ka na ba ng gamot? } \\ \text { 아니요, 못 먹었어요. } & \text { Tina : Hindi pa ako uminom ng gamot. } \\ \text { 내일 아침에 같이 병원에 가요. } & \text { Asawa: Bukas ng umaga sabay tayong pupunta sa ospital. }\end{array}$

Picture 8. Sample dialogue of Tina and Korean husband in Pangunahing Aralin sa Hangugo (Basic). (Fetalvero, 2007)

Similarly, Pi-in's husband is portrayed as a kind husband that her wife admires, as seen in their conversation below:

\section{대화}

남 편 집안 일이 힘들지요? 자, 이거 $\cdots$

Mahirap po ang mga pang araw-araw na gawain, hindi po ba? Heto na po.

마하릴 포앙 방아 빔 아라우 아라우 나 가와인, 힌디 포 바?해토 나포.

피 인 이게 뭐예요?

Ano po ito?
아노 모이도?

남 편 오늘이 우리 결혼기념일이에요. 고마워요. 그리고사랑해요.

Ngayon ang araw ng ating kasal. Salamat. At mahal kita.
느는 앙 아라우 난 이팅 카살. 살리마트 이므 마할 기타.

피 인 많이 도와주니까 제가 고마워요.

Salamat sa iyo dahil sa dami ng naitulong mo sa akin. 살라마트사 이으 다힐 사 다미 님 나이투름 모 사 아킨.

남 편 고향집에 많이 가고 싶지요?

Ayaw mo bang umuwi sa bayan mo?

아야우 모 방 우모워사 비안 오?

농사 시작하기 전에 갔다 와도 돼요.

Maaari ka ng umuwi bago magsimula ang p

인 정말 친절한 남편이에요. 너무 감동 샀어요.

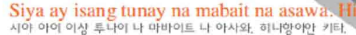

Picture 9. Sample dialogue of Tina and Korean husband in Pangunahing Aralin sa Hangugo (Basic). (Fetalvero, 2007)

\section{Sociocultural Practices: Korean Style of Assimilation}

The Filipino/Tagalog translated textbooks are part of the wider sociocultural practice of the Korean government's multicultural policy. "Korean style multiculturalism" is by nature more similar to assimilation than multiculturalism (Lee, 2015). According to Robert Park and Ernest Burgess (as cited in Gordon, 1964), assimilation is a process of interpenetration and fusion in which persons and groups acquire the memories, sentiments, and attitudes of other persons or groups, and, by sharing their experience and history, are incorporated with them in a common cultural life. Gordon identifies seven types or stages of assimilation: cultural or behavioral assimilation (acculturation), structural assimilation (integration), marital assimilation (intermarriage), identificational assimilation, attitude receptional assimilation, behavior receptional assimilation, and civic assimilation. Among these stages of assimilation, the first three types seem to be applicable in this study. 
First is the cultural assimilation or acculturation that takes place when the minor group learns the culture, language, and values of the dominant group. The best way to assimilate Filipina marriage migrants to the dominant/ paternal Korean culture is through language since language and culture are intertwined. The government institutions MOGEF and MAFRA are fully aware of the impact of an individual's native language, Filipino/ Tagalog in this case, in introducing and studying the Korean language. According to Douglas Brown (2007), native language, being the only source of knowledge of the learner, facilitates in his or her learning a second language. This is true especially in the early stage of language learning. It is worth mentioning that government ministries produced Filipino/Tagalog translated textbook for beginners only, not for intermediate and advanced levels. Using Filipino/ Tagalog language to learn the basics of Korean language facilitates a better understanding of not just the grammar rules and usage of Korean but also its cultural component. In this case, the government recognized and used the native language of marriage migrants as a tool to hasten the learning of Korea's language and culture.

Another stage in assimilation is structural assimilation or integration. It simply means that the members of the minority group enter the cliques, clubs, friendship, public institutions, and organizations of the dominant society. Language also plays a major role in this. In the translated Filipino/ Tagalog books for Korean language learning, there are topics related to integration like introducing oneself, asking and telling time, direction and location, stating the condition of one's health, making simple transactions and cooking and stating one's favorite food. As previously mentioned, the textbooks are highly contextualized for Filipina marriage migrants as they cover topics related to preparing food for the family, taking care of the husband, child/ren and in-laws, going to and purchasing things in the market, and even about farming. It is not surprising that MOGEF published textbooks related to Korean language education because it is quite obvious that this agency is related to multicultural family education. However, it may be quite surprising that the women's division of MAFRA also sponsored a book related to Korean language learning. Actually, this is highly connected to the demographics of the marriage migrants in Korea. There has for some time been a severe shortage of South Korean women willing to marry rural South Korean men, especially farmers and fishermen, who have looked to other countries for their marriage partners (Son, 2012). And as shown in Table 2, most of the marriage migrants are women, and majority of them also come from developing countries such as Vietnam, Philippines, Thailand, Cambodia, and Mongolia. Thus, that MAFRA's textbook targets marriage migrants staying in the rural areas and tries to integrate them to rural life 
by including topics such as digging potatoes, planting pepper and ginger, and drying up radish and peppers becomes much clearer. The integration will not be smooth if the minority group member does not fully grasp the dominant group's language. However, while marriage migrants have not yet mastered the Korean language, the translated Filipino/Tagalog texts serve as their only reference or guide.

According to Joseph Healey (2009), when integration into the primary sector becomes substantial, people are more likely to select spouses from among their primary relations. However, in this case, the Filipina marriage migrants married their Korean husbands, so they have to live in Korea and need to integrate/assimilate themselves in Korean society. Since many of the marriage migrants come from poor families, they opt to stay and live in Korea to have better lives. As a consequence, they need to assimilate and integrate themselves in a patriarchal and hierarchical Korean society.

\section{Conclusion}

"Korean style multiculturalism," which is more inclined to a policy of assimilation, gave way to Filipino/Tagalog translated texts in Korean society. The textbooks were produced to facilitate the Filipina marriage migrants' integration to Korean society. In these textbooks, it was observed in the dialogues that both the marriage migrants who are living in the city and the rural or farming areas need to learn the Korean language and culture to fulfill their duties as mother, wife, daughter-in-law, and assimilated foreigner in the Korean society. Based on the critical discourse analysis, Filipino/ Tagalog language is used in the textbooks produced by different Korean government agencies to facilitate mastery of the Korean language, to help imbibe the Korean culture, and to acculturate, assimilate and integrate the marriage migrants into the "multicultural" society of Korea. 


\section{References}

Bloor, M., \& Bloor, T. (2007). The practice of critical discourse analysis. London: Hodder Education.

Brown, H. D. (2007). Principles of language learning and teaching (5th ed.). London: Prentice Hall Inc.

Healey, J. F. (2009). Race, ethnicity, gender and class: The sociology of group conflict and change. Los Angeles: Sage Publications.

Fairclough, N. (1995). Critical discourse analysis: The critical study of language. London: Longman.

Fetalvero, N. (Trans). (2007). 여성 결혼이민자를 위한 한국어교재 (타갈로그어 초급) [Pangunahing aralin sa Hangugo para sa mga imigranteng kababaihan]. Retrieved from http://nuri.sejonghakdang. org/upload/ebook/contents/e_book_15/index.html.

Gordon, M. (1964). Assimilation in American life: The role of race, religion, and national origins. New York: Oxford University Press.

Jo, S., Kim, M., Woo, l., Woo, C., \& Lee, M. (2007). 농촌 여성결혼이민자를 위한 한국어 우리 엄마의 한국어 [My mom's Korean Language (Basic) (Tagalog)]. Gyeonggi-do: Ministry of Agriculture and Forestry Women's Division.

Kim, J. K. (2011). The politics of culture in multicultural Korea. Journal of Ethnic and Migration Studies, 37(10), 1,583-1,604.DOI: 10.1080/1369183X.2011.613333.

Kim, N. H. (2012). Multiculturalism and the politics of belonging: The puzzle of multiculturalism in South Korea, Citizenship Studies, 16(1), 103-117, DOI: 10.1080/13621025.2012.651406.

Korea Immigration Service. (2016). 2016 출입국•외국인정책 통계연보 [Annual report of arrivals, departures, and foreigners' policy statistics]. Retrieved from http://www.immigration.go.kr/HP/ TIMM/index.do?strOrgGbnCd=104000.

Laranjo, R., \& Shin, S. (2016). Patterns of errors in composition of Korean learners of Filipino language. The Southeast Asian Review, 26(4), 365-404.

Lee, Y. S. (2015). Discussion on multiculturalism in Korea. OMNES, 5(2), 85-114.

Mabanglo, R.E.(1997). Pagpapahusay ng Filipino sa mga Filipino/Di-Filipino sa labas ng Filipinas. Daluyan: Journal ng SWF sa Talakayang Pangwika, 8(1-2), 35-48.

Oue, M. (1997). Ang pagpapahusay sa pagtuturo ng Filipino sa mga estudyanteng Hapones:Mga suliranin at solusyon. Daluyan: Journal ng SWF sa Talakayang Pangwika, 8(1-2), 21-34.

Ramos, T., \& Mabanglo, R. (2012). Southeast Asian language teaching: The language learning framework for teachers of Filipino, special issue. Retrieved from http://cotseal.net/cotseal/pages/documents/ Journal_of_SEA_Filipino_2012.pdf.

Son, J. (2012). Korean textbooks for foreign residents in Korea: Imagined communities and limited possibilities. Paper read in World Congress of Korean Studies. Republic of Korea

Watson, I. (2010). Multiculturalism in South Korea: A critical assessment. Journal of Contemporary Asia, 40(2), 337-346. DOI: 10.1080/00472331003600549.

Yap, F. A. (2012). Global Filipino crossing borders. Manila: De La Salle University Publication House. 


\section{Achnowledgement}

The draft of this paper was presented at the 2016 Philippine Korean Studies Symposium (PKSS) - Korean Studies Workshop for Academicians in the Philippines organized by the UP Department of Linguistics, at Microtel Wyndham Technohub, July 20-22,2016. The event was supported by the Academy of Korean Studies Grant (AKS-2016-K27).

RONEL O.LARANJO is a faculty member of Department of Filipino and Philippine Literature in University of the Philippines. He is also a freelance translator, semanticist, and teacher of Filipino language to foreign students. He is currently finishing his coursework in PhD Filipino Language Structure in the same university. He obtained his master's degree (MA Applied Linguistics) in Korea University and his undergraduate degree (BA Filipino) in UP Diliman (corresponding author:ronel_laranjo@yahoo.com). 